\title{
A study on relationship between abnormal accruals and future profitability: Evidence from Tehran Stock Exchange
}

\author{
Mohammad Khodaei Valahzaghard $^{\mathrm{a}^{*}}$ and Samaneh Refahi Bakhsh
}

\begin{abstract}
${ }^{a}$ Assist. Prof. \& Faculty Member, Department of Accounting, School of Management and Human Sciences, Tehran North Branch, Islamic Azad University (IAU), Tehran, Iran

${ }^{b}$ M.Sc. Student, Department of Accounting, School of Management and Human Sciences, Tehran North Branch, Islamic Azad University (IAU), Tehran, Iran

C H R O N I C L E

Article history:

Received June 22, 2013

Received in revised format

28 August 2013

Accepted 18 September 2013

Available online

September 212013

Keywords:

Tehran Stock Exchange

Future profitability

Abnormal Accruals

Accruals A B S T R A C T

This paper presents an empirical investigation to study the relationship between future profitability and abnormal accruals on selected firms from Tehran Stock Exchange (TSE). The study selects 223 firms from TSE market over the period 2007-2011. Using the regression analysis, the study shows there was no meaningful relationship between abnormal earnings and future profitability when the level of significance is five percent. There are also seven subhypotheses associated with the proposed study of this paper. The results indicate that while there were no meaningful relationship between firm size, capital expenditure, earnings quality and earning forecasted error on one side and future earnings, the study confirms a significance relationship between ratio of book value to equity as well as market leverage and future earnings.
\end{abstract}

\section{Introduction}

During the past few years, there have been tremendous efforts on learning the effects of abnormal accrual on future earnings. Ali et al. (2000) investigated whether the association between accruals and future returns reported by Sloan (1996) was because of fixation by naïve investors on the total amount of reported earnings without any association for the relative magnitude of the accrual and cash flow items. Contrary to the expectations of the naïve investor hypothesis, they reported that the predictive capability of accruals for subsequent annual returns and for quarterly earnings announcement stock returns was not lower for large firms. In addition, they reported that the capability of accruals to forecast future returns would not seem to depend on stock price or transaction volume, measures of transaction costs, also contrary to anticipations of the naïve investor 
hypothesis. They also concluded that the predictive ability of accruals for subsequent returns did not appear to be because of the inability of market participants to understand value-relevant information.

Barth et al. (2001) proposed a model based on the Dechow et al. (1998) model of the accrual process and investigated the role of accruals in forecasting future cash flows. The model demonstrated that each accrual component would reflect various information associated with future cash flows. They reported that disaggregating accruals into major components - change in accounts receivable, change in inventory, change in accounts payable, amortization, depreciation and other accruals influence predictive capabilities. Each accrual item, including depreciation and amortization, was significant with the predicted sign in predicting future cash flows, incremental to current cash flow. The cash flow and accrual components of current earnings had more predictive capability for future cash flows than several lags of aggregate earnings.

Chan et al. (2001) explored different hypotheses on earnings manipulation, extrapolative biases about future growth, and under-reaction to business conditions to describe accruals' predictive power. They reported that distinctions between the hypotheses were based on evidence from operating performance, the behavior of individual accrual items, and discretionary versus nondiscretionary components of accruals. Dechow (1994) investigated different conditions that accruals were predicted to improve earnings' ability to measure firm performance, as reflected in stock returns. They predicted cash flows to suffer more severely from timing and matching problems, which reduce their ability to reflect firm performance. Dechow and Dichev (2002) proposed a new method of one aspect of the quality of working capital accruals and earnings. They reported that observable firm characteristics could be implemented as instruments for accrual quality and explained that the proposed measure of accrual quality was positively associated with earnings persistence.

Hirshleifer et al. (2009) examined whether the firm-level accrual and cash flow effects extend to the aggregate stock market. One the contrary on previous firm-level findings, aggregate accruals was a strong positive time series predictor of aggregate stock returns, and cash flows was a negative predictor. They also reported that, innovations in accruals were negatively associated with aggregate returns, and innovations in cash flows were positively correlated with returns. These findings recommended that innovations in accruals and cash flows contained information about changes in discount rates, or that firms manage earnings in response to market wide undervaluation. Richardson et al. (2001) extended the analysis in Sloan (1996) to root the source of information in accruals about earnings quality. The results indicated that information in accruals about earnings quality was not limited to the current accruals analyzed by Sloan, but extended to non-current accruals. They also demonstrated that while information in accruals originated exclusively from asset accruals, liability accruals played a useful impact in helping to isolate information in asset accruals about earnings quality. Teoh et al. (1998) explained issuers of initial public offerings (IPOs), which can yield earnings in excess of cash flows by taking positive accruals.

They provided some evidence that issuers with unusually high accruals in the IPO year experience poor stock return performance in the three years thereafter. Xie (2001) examined the market pricing of Jones (1991) model estimated abnormal to see whether stock prices rationally could reflect the one-year-ahead earnings implications of these accruals. They suggested that the overpricing of total accruals that Sloan (1996) documents was due largely to abnormal accruals. Yasuda et al. (2004) investigated the relationship between bank risk and earnings management and reported that shows that bank risk was negatively associated with discretionary accruals, indicating that investors misinterpreted high reported earnings as favorable information about bank financial health.

\section{The proposed model}

The proposed study of this paper examines the relationship between abnormal accruals and future profitability. The main hypothesis of this survey is as follows, 
Main hypothesis: There is a meaningful relationship between abnormal accruals and future profitability.

The dependent variable in this survey is the change on return of assets (ROA) in two consecutive periods of $t$ and $t+1$ as follows,

$\triangle \mathrm{ROA}=\mathrm{ROA}_{\mathrm{it}+1}-\mathrm{ROA} \mathrm{A}_{\mathrm{it}}$.

In our survey, abnormal accruals is calculated from the residual of the following relationship,

$T A_{i t} / A_{i t ~-1}=\beta_{1}\left(1 / A_{i t-1}\right)+\beta_{2}\left(\left(\Delta R E V_{i t}-\Delta R E C_{i t}\right) / A_{i t-1}\right)+\beta_{3}\left(P P E_{i t} / A_{i t-1}\right)+\beta_{4}\left(R O A_{i t-1}\right)+\varepsilon$,

where total accrual (TA) is calculated as follows,

$\mathrm{TA}_{\mathrm{it}}=\left(\Delta \mathrm{CA}_{\mathrm{it}}-\Delta \mathrm{CASH}_{\mathrm{it}}\right)-\left(\Delta \mathrm{DCL}_{\mathrm{it}}-\Delta \mathrm{STD}_{\mathrm{it}}\right)-\mathrm{DEP}_{\mathrm{it}}$,

where $\triangle C A_{i t}$ is the change on current assets, $\triangle C A S H_{i}$ is the change on cash, $\triangle D C L_{i}$ is the change on current liabilities in two consecutive years, $\triangle S T D_{i t}$ is the change on long term liabilities, $D E P_{i t}$ is the cost of depreciation of tangible and intangible assets, $\triangle R E V_{i t}$ is the change on revenue in two consecutive years, $\triangle R E C_{i t}$ is the change on net receivable accounts in two consecutive years, $P P E_{i t}$ is the growth value of equipment, $R O A_{i t-1}$ is the return on assets for $t-1$ and $\varepsilon_{i t}$ is the residuals.

In addition, there are several control variables used for the proposed study of this paper. In our survey, $B M_{i t}$ is the ratio of book value/market value, $C a p E x_{i t}$ is the ratio of net property/ $\mathrm{A}_{\text {it- } 1}$ where $A$ represents total assets. Size of the firm is calculated by taking natural logarithm of total Assets, quality of earnings is also calculated as the ratio of operating cash flow on net income $\mathrm{EQ}_{\mathrm{it}}=\mathrm{OCF} / \mathrm{NI}$. Earning forecasted error is calculated as the change on earnings per share (EPS) in two consecutive years as $\mathrm{EFE}_{\mathrm{it}}=\left(\mathrm{EPS}_{\mathrm{R}}-\mathrm{EPS}_{\mathrm{F}}\right) / \mathrm{EPS}_{\mathrm{R}}$. Finally, market leverage is calculated as a ratio of $\mathrm{ML}_{\mathrm{it}}$ $=$ Debt/Market Value of Equity and book value leverage is measured as the ratio of $B L_{i t}=$ Debt $/ B o o k$ Value of Equity. The proposed study gathered the historical information of 223 firms over the period of 2006-2011, which yields 1115 year-firm data. Table 1 demonstrates some basic information associated with the proposed study of this paper.

\section{Table 1}

The summary of basic information

\begin{tabular}{lccccccccc}
\hline \multirow{2}{*}{ Variable } & \multirow{2}{*}{$\mathrm{N}$} & \multicolumn{2}{c}{ Attribute } & \multicolumn{2}{c}{ Diversity } & \multicolumn{2}{c}{ Distribution } & \multicolumn{2}{c}{ Deviation } \\
\cline { 3 - 9 } & & Mean & Median & Std. dev. & Variance & Skewness & Kurtosis & Skewness & Kurtosis \\
\hline \multirow{2}{*}{ AbOA } & 1115 & -0.0096 & -0.0096 & 0.13111 & 0.018 & -1.20496 & 22.76405 & -11.917 & 130.020 \\
Abnormal accruals & 1113 & -0.679 & -0.645 & 0.4878 & 0.240 & -0.38024 & 5.523500 & -4.5616 & 17.312 \\
BM $_{i t}$ & 1108 & 0.7460 & 0.6387 & 0.9156 & 0.958 & 8.67787 & 158.9924 & 113.890 & 894.183 \\
CapEx $_{i t}$ & 1114 & 0.2151 & 0.1830 & 0.1632 & 0.027 & 1.272130 & 5.288187 & 18.013 & 16.595 \\
EQ $_{\text {it }}$ & 1115 & 3.547 & 0.9911 & 51.725 & 2606.04 & 26.24165 & 764.6452 & 364.731 & 5380.85 \\
EFE $_{\text {it }}$ & 1092 & 0.10313 & 0.01661 & 8.367 & 69.64 & 14.46268 & 416.2140 & 196.216 & 2819.73 \\
ML $_{\text {it }}$ & 1108 & 2.355 & 1.3647 & 3.714 & 13.70 & 7.74935 & 109.9584 & 105.315 & 725.482 \\
$B_{i t}$ & 1115 & -9.502 & 1.7705 & 360.66 & 126754.5 & -32.772 & 1077.902 & -455.191 & 7586.33 \\
Size & 1115 & 5.76206 & 5.69788 & 0.60061 & 0.358 & 0.636147 & 3.872660 & 8.712 & 6.109 \\
\hline
\end{tabular}

Next we need to figure out whether we should use fixed effect or random effect as well as pooled or panel method. This could be accomplished based on Chaw and Husman tests summarized in Table 2. The results of Table 2 indicate that we must use fixed effect for regression analysis. In addition, we have investigated the correlation among independent variables and our survey did not indicate any strong relationship correlation among independent variables. Therefore, we could rely on the results of regression analysis. 
Table 2

The summary of the results of Chaw and Husman tests

\begin{tabular}{|c|c|c|c|c|c|c|}
\hline \multirow{2}{*}{ Objective } & \multicolumn{3}{|c|}{ Chaw } & \multicolumn{3}{|c|}{ Husman } \\
\hline & F-value & Sig. & Result & Chi-Square & Error level & Result \\
\hline Panel & 0.867744 & 0.9016 & Equal intercept & & & \\
\hline Pool & 17.79501 & 0 & Intercept not equal & 43.93108 & 0 & Fixed effect \\
\hline
\end{tabular}

\section{The results}

In this section, we present details of our investigation on testing the relationship between dependent and independent variables. Table 3 shows details of our findings,

\section{Table 3}

The summary of regression analysis

\begin{tabular}{clcccc}
\hline Symbol & Variable & Coefficient & Standard error & t-student & Sig. \\
\hline C & Intercept & 0.037647 & 0.039658 & 0.949279 & 0.3427 \\
AB & Abnormal accruals & -0.00311 & 0.009994 & -0.31151 & 0.7555 \\
BM & Debt/Market Value of Equity & -0.00982 & 0.004864 & -2.01948 & 0.0437 \\
Cap & Capital expenditure & 0.029804 & 0.029554 & 1.008453 & 0.3135 \\
EQ & Quality of profitability & $-2.52 \mathrm{E}-05$ & $7.87 \mathrm{E}-05$ & -0.31994 & 0.7491 \\
EFE & change on earnings per share & 0.000243 & 0.000486 & 0.501382 & 0.6162 \\
ML & Market leverage & 0.00276 & 0.001212 & 2.276551 & 0.023 \\
BL & Book value leverage & $1.08 \mathrm{E}-05$ & $1.09 \mathrm{E}-05$ & 0.985715 & 0.3245 \\
Size & Size & -0.00951 & 0.006662 & -1.42761 & 0.1537 \\
\hline Durbin-Watson=1.95 F-value $=2.91$ & & & &
\end{tabular}

We now process the main hypothesis as well as other sub-hypothesis of the survey.

\subsection{The main hypothesis}

The main hypothesis of this survey considers whether there is any relationship between abnormal accrual and future profitability as follows,

$$
\left\{\begin{array}{l}
H_{0}: \beta_{R O A, A B}=0 \\
H_{1}: \beta_{R O A, A B} \neq 0
\end{array}\right.
$$

As we can observe from the results of Table 3, the relationship between $\mathrm{ROA}$ and $\mathrm{AB}$ is not meaningful when the level of significance is five percent. Therefore, the main hypothesis of the survey is not confirmed.

\subsubsection{The relationship between firm size and future profitability}

The first sub-hypothesis of this survey investigates the relationship between firm size and future profitability as follows,

$$
\left\{\begin{array}{l}
H_{0}: \beta_{\text {ROA,Size }}=0 \\
H_{1}: \beta_{\text {ROA,Size }} \neq 0
\end{array}\right.
$$

As we can observe from the results of Table 3, the relationship between ROA and size is not meaningful when the level of significance is five percent. Therefore, the first sub-hypothesis of the survey is not confirmed.

\subsubsection{The relationship between ratio of book value to equity and future profitability}

The second sub-hypothesis of this survey investigates the relationship between ratio of book value to equity and future profitability as follows, 


$$
\left\{\begin{array}{l}
H_{0}: \beta_{R O A, B M}=0 \\
H_{1}: \beta_{R O A, B M} \neq 0
\end{array}\right.
$$

As we can observe from the results of Table 3, the relationship between ROA and ratio of book value to equity is meaningful when the level of significance is five percent. Therefore, the second subhypothesis of the survey is confirmed.

\subsubsection{The relationship between capital expenditure and future profitability}

The third sub-hypothesis of this survey investigates the relationship between capital expenditure and future profitability as follows,

$$
\left\{\begin{array}{l}
H_{0}: \beta_{R O A, C a p}=0 \\
H_{1}: \beta_{R O A, C a p} \neq 0
\end{array}\right.
$$

As we can observe from the results of Table 3, the relationship between ROA and capital expenditure is not meaningful when the level of significance is five percent. Therefore, the third sub-hypothesis of the survey is not confirmed.

\subsubsection{The relationship between earnings quality and future profitability}

The fourth sub-hypothesis of this survey investigates the relationship between earning quality and future profitability as follows,

$$
\left\{\begin{array}{l}
H_{0}: \beta_{R O A, E q}=0 \\
H_{1}: \beta_{R O A, E q} \neq 0
\end{array}\right.
$$

As we can observe from the results of Table 3, the relationship between ROA and earnings quality is not meaningful when the level of significance is five percent. Therefore, the fourth sub-hypothesis of the survey is not confirmed.

\subsubsection{The relationship between earning forecasted error and future profitability}

The fifth sub-hypothesis of this survey investigates the relationship between earning forecasted error and future profitability as follows,

$$
\left\{\begin{array}{l}
H_{0}: \beta_{R O A, E F E}=0 \\
H_{1}: \beta_{R O A, E F E} \neq 0
\end{array}\right.
$$

As we can observe from the results of Table 3, the relationship between ROA and earning forecasted error is not meaningful when the level of significance is five percent. Therefore, the fifth subhypothesis of the survey is not confirmed.

\subsubsection{The relationship between market leverage and future profitability}

The sixth sub-hypothesis of this survey investigates the relationship between market leverage and future profitability as follows,

$$
\left\{\begin{array}{l}
H_{0}: \beta_{R O A, M L}=0 \\
H_{1}: \beta_{R O A, M L} \neq 0
\end{array}\right.
$$

As we can observe from the results of Table 3, the relationship between ROA and market leverage is meaningful when the level of significance is five percent. Therefore, the sixth sub-hypothesis of the survey is confirmed. 


\subsubsection{The relationship between book value leverage and future profitability}

The seventh sub-hypothesis of this survey investigates the relationship between book value leverage and future profitability as follows,

$$
\left\{\begin{array}{l}
H_{0}: \beta_{R O A, B L}=0 \\
H_{1}: \beta_{R O A, B L} \neq 0
\end{array}\right.
$$

As we can observe from the results of Table 3, the relationship between ROA and book value leverage is not meaningful when the level of significance is five percent. Therefore, the last subhypothesis of the survey is not confirmed.

\section{Conclusion}

In this paper, we have presented an empirical investigation to study the relationship between abnormal accrual and future earnings for selected firms listed on Tehran Stock Exchange. The results indicated that while there were no meaningful relationship between firm size, capital expenditure, earnings quality and earning forecasted error on one side and future earnings, the study confirmed a significance relationship between ratio of book value to equity as well as market leverage and future earnings.

\section{References}

Ali, A., Hwang, L. S., \& Trombley, M. A. (2000). Accruals and future stock returns: Tests of the naïve investor hypothesis. Journal of Accounting, Auditing \& Finance, 15(2), 161-181.

Barth, M. E., Cram, D. P., \& Nelson, K. K. (2001). Accruals and the prediction of future cash flows. The Accounting Review, 76(1), 27-58.

Chan, K., Chan, L. K., Jegadeesh, N., \& Lakonishok, J. (2001). Earnings quality and stock returns (No. w8308). National Bureau of Economic Research.

Dechow, P. M. (1994). Accounting earnings and cash flows as measures of firm performance: The role of accounting accruals. Journal of accounting and economics, 18(1), 3-42.

Dechow, P. M., Hutton, A. P., \& Sloan, R. G. (1999). An empirical assessment of the residual income valuation model. Journal of accounting and economics, 26(1), 1-34.

Dechow, P. M., \& Dichev, I. D. (2002). The quality of accruals and earnings: The role of accrual estimation errors. The accounting review, 77(s-1), 35-59.

Hand, J. R. (1990). A test of the extended functional fixation hypothesis. Accounting Review, 740763.

Hirshleifer, D., Hou, K., \& Teoh, S. H. (2009). Accruals, cash flows, and aggregate stock returns. Journal of Financial Economics, 91(3), 389-406.

Jones, J. J. (1991). Earnings management during import relief investigations.Journal of accounting research, 29(2), 193-228.

Richardson, S., Sloan, R., Soliman, M., \& Tuna, A. (2001). Information in accruals about the quality of earnings. Information in Accruals About the Quality of Earnings (July 2001).

Sloan, R. G. (1996). Do stock prices fully reflect information in accruals and cash flows about future earnings?. Accounting Review, 289-315.

Teoh, S. H., Welch, I., \& Wong, T. J. (1998). Earnings management and the long-run market performance of initial public offerings. The Journal of Finance, 53(6), 1935-1974.

Xie, H. (2001). The mispricing of abnormal accruals. The accounting review,76(3), 357-373.

Yasuda, Y., Okuda, S. Y., \& Konishi, M. (2004). The relationship between bank risk and earnings management: evidence from Japan. Review of Quantitative Finance and Accounting, 22(3), 233248. 